\title{
Berlinale 2004 Report
}

\author{
By Ron Holloway \\ Spring 2004 Issue of KINEMA
}

\section{BERLINALE 2004}

"IF I had a choice, the Retrospective would be the Competition!" - quipped Dieter Kosslick at the opening of the $54^{\text {th }}$ Berlinale (5-15 February 2004), his third as festival director. Titled "New Hollywood 1967-1976," and inspired by film historian Peter Biskind's bestseller "Easy Riders, Raging Bulls," the retro embraced the favourite films of veteran critics and film professionals attending the Berlinale. Indeed, the run on tickets for legendary films by cult directors - Roger Corman's Wild Angels (1966), Arthur Penn's Bonnie and Clyde (1967), John Cassavetes's Faces (1968), Dennis Hopper's Easy Rider (1969), Sam Peckingpah's Wild Bunch (1969), Bob Rafelson's Five Easy Pieces (1969), Peter Bogdanovich's Last Picture Show (1971), William Friedkin's French Connection (1971), Jack Nicholson's Drive, He Said (1971), Francis Ford Coppola's Godfather (1972), Brian De Palma's Sisters (1972), Terrence Malick's Badlands (1973), George Lucas's American Graffiti (1973), Hal Ashby's Last Detail (1973), Steven Spielberg's Sugarland Express (1974), Robert Altman's Nashville (1975), Martin Scorsese's Taxi Driver (1976), Emile de Antonio's Underground (1976), and Michael Cimino's The Deer Hunter (1978), plus a dozen others launched at Cannes - underscored just how much this retro deserved a festival showcase all to itself!

To hype the press for "New Hollywood" a bit more, Peter Fonda appeared in person for the screening of The Hired Hand (1971), as did Monte Hellman for The Shooting (1966) and Two-Lane Blacktop (1971), Peter Davis for Hearts and Minds (1974), and Melvin Van Peebles for Sweet Sweetback's Baadasssss Song (1971). The icing on the retro cake was the Panorama screening of Mario Van Peebles's tongue-in-cheek Gettin' the Man's Foot Outta Your Baadassss! (2003), the son's movie version of his father's book about how the original got made in the first place. Produced, directed, edited, scored, and acted-in by Melvin Van Peebles, Sweetback was the first "blaxploitation" film to break the colour barrier at the American box office.

The Berlinale opened with Anthony Minghella's Cold Mountain (USA), shot in Romania and nominated for seven Oscars. Based on Charles Frazier's bestseller, it's the story of a Confederate solder returning home to North Carolina at the close of the American Civil War. Along the way, as in the Odyssey, the heroic Inman (Jude Law) has to overcome many obstacles before reaching his destination. Due to a required appearance by Oscar-nominated personalities in Los Angeles - an event scheduled smack in the middle of the Berlinale - no less than three separate televised visits to the festival were made by the film's principles (Minghella, Law, Renee Zellweger) to help promote the simultaneous launch of Cold Mountain in German cinemas. The opening sequence alone is worth the price of admission: a reenactment of the bomb-crater explosion under the fortifications at Petersburg that resulted in a military disaster for the assaulting Union troops, yet did forecast the end of a bloody Civil War.

Not since 1986, when Reinhard Hauff's Stammheim was awarded the Gold Bear, has a German entry been so honoured. This year, the Grand Prize was awarded to Fatih Akin's Gegen die Wand (Head On), alternately tagged in the press as a "German," a "Turkish," or a "German-Turkish" film. Shot in Hamburg and Istanbul, with episodes interpolated by a Turkish singer and a musical ensemble on the banks of the Bosporus, Fatih Akin doesn't pull his punches in this biting portrayal of the hardships endured by many second-generation Turks in Germany at the crossroads between two cultures. As the title hints, this is the story of two suicideprone young German-Turks, who find and support each other after mutual attempts to end their lives, then marry on a whim to spite the Turkish community, and finally plunge into a downward spiral of drugs, drinking, freewheeling sex, and uncontrolled bursts of temper. Directed by a second-generation filmmaker as much German as he is Turkish, Fatih Akin is a talent to watch in the growing ranks of cross-cultural filmmakers in Germany.

Romuald Karmarkar's Die Nacht singt ihre Lieder (Nightsongs), also selected for the Competition, was the best German film on view at the Berlinale. Based on a play by Norwegian dramatist Jon Fosse, Nightsongs leaves the viewer with little room to breath in sketching the end of a marriage and the utter collapse of a writer's ambitions to finally get a book published. That the roles are listed in the credits simply as "young 
man" (Frank Giering) and "young woman" (Anne Ratte-Polle) hints of a broader context than just a spat between a man and his wife, with the newly born baby as the pawn in the quarrel. Neither are able to communicate with each other, save to note over and over again that their lives are at a standstill. Set in a bohemian flat in Berlin-Kreuzberg, Nightsongs depicts a suffocating world of lost illusions - for none of the couple's friends even bother to visit anymore on the grounds, says the wife, that the husband can't stand their company. A visit by the would-be writer's parents, in from the provinces only to see the baby and then leave, underscores just how moribund the situation is. And when the wife admits to an adulterous affair and the lover arrives on the scene, Nightsongs fades out on a final discordant note.

Respected as much for his documentaries (Warheads, 1992) and video-productions (The Himmler Project, 2000) as for his features (The Death Maker, 1995, Manila, 1999), Romuald Karmakar was also present in the Panorama with Land der Vernichtung (Land of Annihilation), a video documentation on a work-in-progress that drew a hefty pro-and-contra response from the audience. Running at 140 minutes, the video was edited down from 15 hours of material shot with a mini DV-camera at the death camps in Belzec, Sobibor, Treblinka, and Majdanek. Although Land of Annihilation is categorized by Karmakar himself as an aide-memoire to help fashion a concept for a feature film, an account of "Operation Reinhardt" about a police battalion assigned to duty in occupied Poland in 1942/43, the interviews he conducted while researching the project last summer on a trip to Poland are as disturbing as they are enlightening. To Karmakar's credit as a German documentarist (born to a French mother and Iranian father), eyewitnesses evidently find it rather easy to talk to him about horrific times they would much rather forget.

A trio of German films worthy of the Competition were seen in the Panorama and the Perspektive Deutsches Kino. In Andres Veiel's Die Spielwütigen (Addicted to Acting) the director follows four aspiring would-be actors over a seven-year stretch as they apply for admission to a Berlin acting school and, when accepted, "worry about the discrepancy between their expectations and their abilities" (Veiel). Addicted to Acting, which opened the Panorama, was greeted with thunderous applause and confirmed Veiel's status as one of the best documentary filmmakers on the scene today. By contrast, the presence of Daniel Brühl and August Diehl, two popular young actors, in Achim von Borries's Was nützt die Liebe in Gedanken (Love in Thoughts) was reason enough to pack the house for its premiere in the spacious Zoo Palast. Based on a "Berlin school tragedy" that made headlines in June of 1927, this sensational story of a murder and suicide stemming from a "suicide pact" had been filmed twice before in 1929 and 1960. Marcus Mittermeier's Muxmäuschenstill opened the Perspektive after winning the Max Ophüls Prize at the Saarbrücken festival the week before. Shot on a shoestring budget, this is the story of dogooder Mux (played by screenwriter Jan Henrik Stahlberg) whose profession is telling everybody else what to do. A would-be thinker and make-believe philosopher, Mux's observations on the foibles of politicians and media entertainers are pretty much on the mark.

Although overlooked by the jury Theo Angelopoulos's Trilogia: to livadi pou dakris (Trilogy: The Weeping Meadow, Greece) was the best contender for Berlinale honours. Running at three hours, The Weeping Meadow is the first part of a trilogy on Greece during the $20^{\text {th }}$ century - Angelopoulos's opus magnum it will also go down in history as the most expensive Greek production ever made. Of course, the viewer is advised to know a good deal about Greece's pivotal political role in the $20^{\text {th }}$ century. In The Weeping Meadow, covering the years 1919 to 1949, we follow a young couple, Eleni (Alexandra Aidini) and Alexis (Nikos Poursanidis), as they return home from Odessa as refugee children, then as adults must fight for their right to marry, only to be caught up in the country's bitter economic and social upheaval, with Eleni in the end witnessing the death of her twin sons, who had taken different sides in the ensuing Civil War. A film of stunning, choreographed images (cameraman Andreas Sinanos), the most remarkable sequences were shot at a mammoth village-set constructed on the dry bed of a lake that gradually fills with water as the seasons change.

Other festival highlights arrived at the Berlinale from the Sundance festival. Clarize Theron's motivated performance as the lesbian serial killer in Patty Jenkins's Monster (USA) won her a Silver Bear for Best Actress, shared with the impulsive teenager played by Catalina Sandrino Moreno in Joshua Marston's Maria, llena eres de gracia (Maria, Full of Grace, USA/ Columbia), the story of smuggler's ploy to use a woman's body to transport packets of heroin. Both films had been standouts at Sundance but a few weeks before. The Best Actor award went to Daniel Hendler, the questioning youngster in Daniel Burman's El abrazo partido (Lost Embrace, Argentina/ France/ Italy/ Spain), a film that spotlights Argentina's current status as the 
most productive filmland in Latin America despite (perhaps because of) the country's economic woes. And the Silver Bear for Best Director to Kim Ki-duk for Samaria (Samaritan Girl, Republic of Korea) confirms the prolific director as one of Asia's leading talents, although this sad tale of two young girls caught in a web of prostitution leaves little to mull over in the end.

Some timely sociopolitical films by veteran directors are sure to win awards and critical praise elsewhere on the festival circuit. Vinko Bresan's Svjedoci (Witnesses, Croatia), based on Jurica Pavicic's recent novel "Alabaster Sheep," in which a critical stance is taken on the war and its aftermath, augurs well for an open-minded Croatian cinema in the future. It was awarded the Peace Prize. The issue of intercultural relations is treated with insight and sensitivity in Ken Loach's Ae Fond Kiss (UK/ Italy/ Germany/ Spain), the story of a romance between a Pakistani DJ and a Catholic teacher that sparks a clash in Glasgow-Asian communities. The third film in Loach's Scottish trilogy, Ae Fond Kiss was awarded the Ecumenical Prize. Last, but not least, the festival programmed a broad range of films from South Africa in the Official Program and the International Forum of Young Cinema. Particularly disappointing was John Boorman's competing Country of My Skull (UK/ Ireland), a chronicle of the "Truth and Reconciliation Commission" in 1995 to heal the wounds in post-apartheid South Africa that rarely rises about the cliché in regard to issues at hand. If you wanted to know something about South Africa today, however, then the ten short films titled Project 10 - Real Stories from a Free South Africa (South Africa) was the collection to see in the Forum.

Two awarded Asian films in the Forum were standouts. Rakesh Sharma's Final Solution (India), awarded the prestigious Wolfgang Staudte Prize, chronicled the issues in 2002/2003 that had spawned hate and violence between Hindus and Moslems in Gujarat, analyzing at the same time the propaganda mechanisms used by political leaders for blatant election purposes. Zhu Wen's Yun de nan fang (South of the Clouds, China), awarded the NETPAC Prize, features a poignant performance by Li Xuejian, a veteran actor, in a sensitive portrayal of a old-timer on a journey across the breadth of China to fulfill a lifetime dream that always seemed just beyond his grasp. Zhu Wen, whose previous feature Hai xian (Seafood, 2001) was invited to Venice but banned in China, is a genuine auteur - a filmmaker with a portfolio of highly acclaimed short stories, poetry, and a novel.

A pair of Thai films at the Forum were warmly welcomed by the press. In Fan Chan (My Girl), co-directed by six filmmakers (Komgrit Threewimol, Songyos Sugmakanan, Nithiwat Tharatorn, Vija Kojew, Vithaya Thongyuyong, and Adisorn Tresirikasem), the story is narrated through the eyes of a man returning to his childhood hometown to attend the wedding of a former best friend. Each nostalgic episode reflects the innocence of youth as shared by the ensemble of directors - an experiment that had its flaws as well as its perks. In Nonzee Nimibutr's Okay Baytong a young Buddhist monk leaves his temple to attend the funeral of an older sister, who had died in a terrorist bombing. Faced with the responsibility of caring for his 7-year-old niece, Tum - sensitively played by Puwarit Poompuang - has to adjust to the world of earthly pleasures.

Comedy is making headway these days in Asian cinema. In Johnnie To's Da zhi lao (Running on Karma, Hong Kong/ China) a hapless ex-Buddhist monk skilled in the arts of Kung Fu is arrested by a friendly woman cop when he accidentally hinders the arrest of a wanted murderer - the first of many twists in fastpaced thriller. Japanese director Sabu (real name: Hiroyuki Tanaka), whose Blessing Bell was awarded the NETPAC Prize last year, returned to the Forum for the fourth time with Hard Luck Hero, a chase film with luckless heroes and trigger-happy gangsters that links three stories around a boxing match in a fast-moving narrative. By the same token, black humour is interspersed in Morisaki Azuma's Niwatori wa hadashi da (Barefoot Chicken, Japan), a family film about a retarded youngster foiling the bad guys in the veteran director's patented "do-geki" (angry drama) in which ordinary people stand up to the injustice of the almighty. In Partho Sen Gupta's Hava aney dey (Let the Wind Blow, India), set in Mumbai against the background of the Indian-Pakistani conflict, a city is portrayed in the grips of economic reform and new lifestyles replacing old traditions - not to mention an atom bomb threat! And in William Kwok Wai Lun's You Gou (Darkness Bride), set in an isolated Chinese village, an autistic lad is the odd figure of a threesome love affair that confronts a community warped by ancient rituals.

Last, but certainly not least, there was the second edition of the Berlinale Talent Campus, now an estimated 1-million-Euro (!) endeavour financed by private sponsors. The Campus drew hundreds to his program at the Haus der Kulturen der Welt in Tiergarten Park. Pegged in a Sight \& Sound article as the Berlin answer 
to the Rotterdam's CineMart, the question now is how Cannes will react. Word is out that Gilles Jacob will launch a Producers Network come next May. Meanwhile, the Berlinale Talent Campus will go on tour to the Cinefan festival in New Delhi in June.

\section{References}

AWARDS

INTERNATIONAL JURY

Golden Bear

Gegen die Wand (Head On, Germany), Fatih Akin

Silver Bear, Grand Jury Prize

El abrazo partido (Lost Embrace, Argentina/ France/ Italy/ Spain), Daniel Burman

Silver Bear, Best Director

Kim Ki-duk, Samaria (Samaritan Girl, Republic of Korea)

Silver Bear, Best Actress (ex aequo)

Catalina Sandrino Moreno, Maria, llena eres de gracia (Maria, Full of Grace, USA/ Columbia), Joshua Marston

Charlize Theron, Monster (USA), Patty Jenkins

Silver Bear, Best Actor

Daniel Hendler, El abrazo partido (Lost Embrace, Argentina/ France/ Italy/ Spain), Daniel Burman

Silver Bear, Individual Artistic Contribution

Entire Ensemble, Om jag vänder mig om (Daybreak, Denmark), Björn Runge

Silver Bear, Best Film Music

Banda Osiris, Primo amore (First Love, Italy), Matteo Garrone

AGICOA Blue Angel Prize, Best European Film

Om jag vänder mig om (Daybreak, Denmark), Björn Runge

Alfred Bauer Prize, for Particular Innovation

Maria, llena eres de gracia (Maria, Full of Grace, USA/ Columbia), Joshua Marston

Golden Bear, Short Film

Un cartu de Kent I un pachet de cafea (Cigarrettes and Coffee) (Romania), Cristi Puiu

Silver Bear, Short Film

Vet! (Great!, Netherlands), Karin Junger, Brigit Hillenius

Special Mention

Public/Private (Argentina), Christoph Behl

Prix UIP Berlin Short Film Award - Competition

Un cartu de Kent I un pachet de cafea (Cigarrettes and Coffee, Romania), Cristi Puiu

\section{OTHER AWARDS}

FIPRESCI Awards

Competition: Gegen die Wand (Head On, Germany), Fatih Akin

Panorama: La face cachée de la lune (Far Side of the Moon, Canada), Robert Lepage

Forum: The Time We Killed (USA), Jennifer Reeves

Ecumenical Awards

Competition: Ae Fond Kiss (UK/ Italy/ Germany/ Spain), Ken Loach 
Special Mention: Svjedoci (Witnesses, Croatia), Vinko Bresan

Panorama: Mi piache lavorare (I Like to Work - Mobbing, Italy), Francesca Comencini

Forum: Folle embellie ( $A$ Wonderful Spell, France/ Belgium/ Canada), Dominique Cabrera

Prize of Guild of German Art House Cinemas

Competition: Ae Fond Kiss, UK/ Italy/ Germany/ Spain), Ken Loach

CICAE Awards (International Confederation of Art Cinemas)

Panorama: O outre lado da rua (The Other Side of the Street, Brazil/ France), Marcos Bernstein

Forum: B-Happy (Chile/ Spain/ Venezuela), Gonzalo Justiniano

Peace Film Prize

Svjedoci (Witnesses, Croatia), Vinko Bresan

Readers' Award of Berliner Morgenpost

Competition: 25 degrés en hiver (25 Degrees in Winter, Belgium/ France/ Spain), Stéphane Vuillet

PANORAMA AWARDS

Panorama Short Film Award

Two Cars, One Night (New Zealand), Taika Waititi

New York Film Academy Scholarship Award - Panorama

Fugue (Australia), James Brown

Special Mention

Le garde de corps (The Bodyguard, France), Sandrine Dumas

LVT - Manfred-Salzgeber-Prize, Innovative European Feature Film

Wild Side (France/ Belgium/ UK), Sebastian Lifshitz

Panorama Audience Award

Die Spielwütigen (Addicted to Acting, Germany), Andres Veiel

Short Film

En del av mitt hjärta (Passing Hearts, Sweden), Johann Brisinger

Teddy Awards

Best Feature Film: Wild Side (France/ Belgium/ UK), Sebastian Lifshitz

Best Documentary: The Nomi Song (Germany), Andrew Horn

Best Short Film: ¿Con qué la lavaré? (With What Shall I wash It?, Spain), Maria Trénor

Special Teddy 2004 - Edition Salzgeber

Readers' Award of Siegessäule Magazine

D.E.B.S. (USA), Angela Robinson

INTERNATIONAL FORUM OF NEW CINEMA AWARDS

Wolfgang Staudte Prize

Final Solution (India), Rakesh Sharma

NETPAC (Network for Promotion of Asian Cinema) Award

Yun de nan fang (South of the Clouds, China), Zhu Wen

Special Mention

Final Solution (India), Rakesh Sharma

Don Quixote Award (International Federation of Film Societies)

Dopo mezzanotte (After Midnight, Italy), Davide Ferrario 
Special Mentions

B-Happy (Chile/ Spain/ Venezuela), Gonzalo Justiniano

Medurat Hashevet (Campfire, Israel), Joseph Cedar

Caligari Award (German Association of Communal Film Work) Dopo mezzanotte (After Midnight, Italy), Davide Ferrario

\section{PERSPEKTIVE DEUTSCHES KINO AWARDS}

Dialogue En Perspektive Award

Flammend' Herz (Blue Skin, Germany/ Switzerland), Andrea Schuler, Oliver Ruts

Special Prize

Der Typ (The Guy, Germany), Patrick Tauss

CHILDREN'S FILM FESTIVAL AWARDS

Crystal Bears - Young People's Jury

Best Feature Film: Magnifico (Philippines), Maryo J. de los Reyes

Special Mentions: Die Blingänger (The Blindgänger, Germany), Bernd Sahling, La prophetie des grenouilles (Raining Cats and Frogs, France), Jacques-Rémy Girerd

Best Short Film: Nuit d'orange (Stormy Night, France/ Canada), Isabelle Favez

Special Mention: Maree (Tides, Italy), James Pekkerito

Crystal Bear - Youth Jury - 14plus - Films for the Young Generation

Best Feature Film: The Wooden Camera (France/ UK/ South Africa), Ntshavheni Wa Luruli

Special Mention: Quality of Life (USA), Benjamin Morgan

Prizes of Deutsches Kinderhilfswerk

Best Feature Film: Magnifico (Philippines), Maryo J. de los Reyes

Special Mentions: Die Blingänger (The Blindgänger, Germany), Bernd Sahling, Barber Yoshino (Yoshino's Barber Shop, Japan), Ogigami

Best Short Film: Lucia (Germany), Felix Gönnert

Special Mentions: Lille Far (Little Daddy, Denmark), Micharl W. Horsten, Cracker Bag (Australia), Glendyn Ivin

BERLINALE CAMPUS AWARDS

Planet Documentary Film Award

Goat Walker (Poland), Bartek Konopka, Piotr Rosolowski

Berlin Today Award

Berlin-Beirut (Lebanon), Myrna Maakaron

Volkswagen Score Competition

Tom Third (Toronto), Sound Recordist, Sound Designer, Composer

\section{Author Information}

Ron HOLLOWAY (1933-2009) was an American critic, film historian, filmmaker and correspondent who adopted Europe as his home in the early fifties and spent much of his life in Berlin. He was an expert on the study of German cinema and against all odds produced, with his wife Dorothea, the journal German Film, keeping us up-to-date with the work of directors, producers and writers and the showing of German films around the world.

In 2007, Ron Holloway and his wife were awarded the Berlinale Camera Award. Ron also received the Bundesverdienstkreuz (German Cross of Merit), Polish Rings, Cannes Gold Medaille, the American Cinema 
Foundation Award, the Diploma for Support of Russian Cinema and an honorary award from the German Film Critics' Association.

Ron was also a valued contributor to Kinema for the past fifteen years. 